\title{
Wastage of blood components in a rural tertiary care neonatal unit: A retrospective hospital-based study
}

\author{
Prabodh Chandra Mondal ${ }^{1}$, Rincy Mathew ${ }^{2}$, Asaduzzaman Laskar ${ }^{2}$, Dhruba Kumar Mahata ${ }^{3}$.
}

Sri Lanka Journal of Child Health, 2021; 50(4): 687-691

DOI: http://doi.org/10.4038/sljch.v50i4.9888

\begin{abstract}
Introduction: Neonates who are critically ill receive frequent blood transfusion during their stay in the neonatal unit. Wastage of blood components is crucial in the functioning of a blood bank.
\end{abstract}

Objectives: To find out the total frequency and volume of transfusions in a neonatal unit for a period of one year, to find out the total amount of blood component wastage following neonatal transfusions with respect to birth weight and gestational age and to find out the number of donor exposures in neonates who are receiving multiple transfusions with respect to frequency of transfusion.

Method: Data regarding blood transfusion and its components were collected retrospectively and analysed with respect to birth weight and gestational age. These data were used to find out the wastage of blood components and donor exposure.

Results: Packed red blood cell transfusion was the most common transfusion in the sick neonate. As birth weight decreased, wastage of blood component increased $(\mathrm{p}<0.05)$. As gestational age decreased wastage of blood component increased $(p<0.05)$. Mean wastage of around $90 \%$ was noticed in the study. Donor exposure to transfusion ratio was $1: 1$.

Conclusions: As birth weight decreased, wastage of blood components increased significantly $(\mathrm{p}<0.05)$. As gestational age decreased, wastage of blood component increased significantly $(\mathrm{p}<0.05)$. Mean wastage of around $90 \%$ was noted in the study. Donor exposure to transfusion ratio was 1:1.

\footnotetext{
${ }^{1}$ Associate Professor, ${ }^{2}$ Post Graduate Trainee, ${ }^{3}$ Resident Medical Officer cum Clinical Tutor, Department of Paediatrics, Midnapore Medical College, Midnapore, West Bengal, India

*Correspondence: dhruba293@gmail.com
}

(iD) https://orcid.org/0000-0003-0344-4179

(Received on 17 October 2020: Accepted after revision on 30 December 2020)

The authors declare that there are no conflicts of interest

Personal funding was used for the project.

Open Access Article published under the Creative

Commons Attribution CC-BY (C) (i) License
(Key words: FFP, Fresh frozen plasma, PRBC, Packed red blood cells, RDP, Random donor platelet).

\section{Introduction}

Neonates who are critically ill receive frequent blood transfusions during their stay in the neonatal unit. Very low birth weight (VLBW) and extremely low birth weight (ELBW) babies often require frequent transfusions. Almost all extremely preterm infants require at least one red blood cell (RBC) transfusion during their stay ${ }^{1}$. It may be due to the normal physiologic process and relatively inefficient erythropoiesis. Reasons for transfusions can be 1) to replace acute loss of blood, 2) to replace chronic blood loss, 3) to stabilize the haemodynamic status i.e. to treat hypotension and 4) to reverse the chronic anaemia that is usually seen at 7-8 weeks of age in preterm infants ${ }^{2}$. Critically ill neonates receive frequent $\mathrm{RBC}$ transfusions of $5-10 \mathrm{ml} / \mathrm{kg}^{3}$. Blood components like packed red blood cells (PRBC), whole blood (WB), fresh frozen plasma (FFP), platelets and cryoprecipitate are used for transfusion depending on the clinical condition. Blood transfusion has many inherent risks ranging from mismatched transfusion and transmission of infectious agents to graft versus host disease.

Hospital blood bank should maintain adequate supplies of blood to meet the demands from patients. Each and every drop of blood is precious. Wastage of blood is highly undesirable. Most of the blood banks face shortage of blood components at a given point of time. Shortage and wastage of the blood are both crucial in the proper functioning of a blood bank. Wastage of blood components in the neonatal unit and related issues are not well researched in the Indian/Asian context. So, hereby we are planning to study the total transfusion requirement and corresponding blood wastage in our set up to address these issues.

\section{Objectives}

- To find out the total frequency and volume of transfusions in a neonatal unit for a period of one year.

- To find out the total amount of blood component wastage following neonatal transfusions with respect to birth weight and gestational age. 
- $\quad$ To find out the number of donor exposures in neonates who are receiving multiple transfusion with respect to frequency of transfusion.

\begin{abstract}
Method
A retrospective observational study was performed in the neonatal unit of a tertiary care centre for a period of one year from January to December 2019. All babies including term, preterm and extreme preterm were included in the study. Subjects were subdivided into $<1000 \mathrm{~g}, 1000-1499 \mathrm{~g}, 1500-2499 \mathrm{~g}$ and $\geq 2500 \mathrm{~g}$. Babies with surgical disorders and congenital anomalies were excluded. The transfusion records of the babies were reviewed to determine the amount and number of transfusions and the total number of donor exposures. All details regarding weight, gestational age, diagnosis, and comorbid illness were recorded.
\end{abstract}

Blood transfusion related details were recorded (frequency, amount, type of blood component). Number of transfusions with respect to birth weight was calculated. Donor exposure details were also recorded. The criteria for $\mathrm{RBC}$ transfusions used in the sick newborn care unit (SNCU) was based on British Committee for Standards in Haematology (BCSH) guideline. Amount of blood transfused was $10-20 \mathrm{ml} / \mathrm{kg}$ per transfusion. FFP, PRBC, random donor platelet (RDP) and WB were the blood components used in our neonatal unit.

From our blood bank we received four types of blood components mainly, PRBC, FFP, WB, and RDP with packet sizes of $250 \mathrm{~mL}, 180-220 \mathrm{~mL}, 320$ $360 \mathrm{~mL}$, and $50 \mathrm{~mL}$ respectively. For better calculation we considered pack volume of blood components as follows: $250 \mathrm{~mL}$ for PRBC, $200 \mathrm{~mL}$ for FFP, $350 \mathrm{~mL}$ for $\mathrm{WB}$ and $50 \mathrm{~mL}$ for RDP. We utilized blood component at $10-20 \mathrm{~mL} / \mathrm{kg}$. The remaining amount of each pack of the blood component was discarded. The blood bank in our Institute does not have any provision either to supply a small size pack or to prepare a satellite pack of different blood component for neonate. We do not have sufficient facilities to keep the unused blood component in our SNCU after using the required amount of blood components. On the other hand, our blood bank also refuses to preserve the remaining huge amount of unused blood component for future utilization of same patients due to lack of facilities. Therefore, in any blood component transfusion a huge amount of unused blood component is discarded even in a blood crisis situation. So, unwillingly, we have to discard that huge amount of unused blood packet into the dustbin as per biohazard management

Ethical issues: Ethical permission to conduct the retrospective study in the SNCU was obtained from the Medical Superintendent cum Vice Principal, Midnapore Medical College and Hospital, Midnapore, India. Confidentiality of data was maintained.

Statistical issues: Data were entered in Microsoft Excel and analysis was done using SPSS version 22. Qualitative variables were expressed as frequency and percentages. Quantitative variables were expressed as mean and standard deviation. Comparison of quantitative variables were done using ANOVA and a $p$ value $<0.05$ was considered to be statistically significant.

\section{Results}

A total of 3863 babies were admitted in the neonatal unit from January to December 2019. Of this, 110 babies had birth weights $<1000 \mathrm{~g}, 481$ had birth weights 1000-1499g, 1645 had birth weights 1500 $2499 \mathrm{~g}$ and 1632 babies had birth weights $2500 \mathrm{~g}$ or more. Of the total, 660 babies had a gestational age (GA) $<34$ weeks, 1170 had a GA between 34 to 37 weeks and 2038 babies had a GA more than 37 weeks. Of the admitted babies 3086 babies were discharged successfully, while 140 babies were referred to other units for surgical intervention and further evaluation. About 513 babies expired during the treatment period in our SNCU and 116 had left against medical advice (LAMA).

During the study period 175 babies had received blood component transfusions 281 times and we conducted our study with these 281 blood component transfusions. There were no incomplete or inaccessible records. Of the study subjects 41 (14.7\%) had birth weight <1000g, 79 (28.1\%) had birth weights between 1000-1499g, $110(39.1 \%)$ had birth weight between $1500-2499 \mathrm{~g}$ and $51(18.1 \%)$ had birth weight $\geq 2500 \mathrm{~g}$. Out of the total 281 transfusions, $64.8 \%$ were PRBC transfusion and $27 \%$ were FFP transfusion.

As depicted in Table 1, PRBC transfusion contributed to around $78 \%$ in those babies who received transfusion with birth weight $<1000 \mathrm{~g}$, whereas FFP transfusion contributed to around $22 \%$. In those babies with birth weight $1000-1499 \mathrm{~g}$, out of the total transfusion $67.1 \%$ transfusions were PRBC transfusion followed by FFP transfusion $(27.8 \%)$. Similar trend was noted in higher birth weight babies. PRBC was the most common blood component used for transfusion in our neonatal unit. 
Table 1: Blood component transfusion, wastage and donor exposure in neonates $(n=281)$

\begin{tabular}{|c|c|c|c|c|}
\hline Characteristic & $<1000 g$ & 1000-1499g & $1500-2499 \mathrm{~g}$ & $\geq 2500 \mathrm{~g}$ \\
\hline Frequency & 41 & 79 & 110 & 51 \\
\hline Percentage & 14.7 & 28.1 & 39.1 & 18.1 \\
\hline Blood component transfusion & & & & \\
\hline Fresh frozen plasma $($ FFP $)-\mathrm{n}(\%)$ & $09(22)$ & $22(27.8)$ & $31(28.2)$ & $14(27.5)$ \\
\hline Packed red blood cells $(\mathrm{PRBC})-\mathrm{n}(\%)$ & $32(78)$ & $53(67.1)$ & $65(59.1)$ & $33(64.7)$ \\
\hline Random donor platelet (RDP) $-\mathrm{n}(\%)$ & $0(0)$ & $03(03.8)$ & $07(06.4)$ & $0(0)$ \\
\hline Whole blood (WB) $-\mathrm{n}(\%)$ & $0(0)$ & $01(01.3)$ & $07(06.4)$ & $04(07.8)$ \\
\hline Volume of transfusion $(\mathrm{ml})-$ Mean \pm SD & $12.90 \pm 3.21$ & $16.24 \pm 4.0$ & $26.37 \pm 9.37$ & $32.23 \pm 14.92$ \\
\hline ANOVA & \multicolumn{4}{|c|}{$\mathrm{F}=52.572 ; \mathrm{p}<0.001$} \\
\hline Wastage $(\mathrm{ml})-$ Mean \pm SD & $228.42 \pm 27.66$ & $213.74 \pm 45.77$ & $201.92 \pm 59.83$ & $211.10 \pm 41.70$ \\
\hline ANOVA & \multicolumn{4}{|c|}{$\mathrm{F}=2.977 ; \mathrm{p}<0.05$} \\
\hline Wastage $(\%)-$ Mean \pm SD & $94.67 \pm 2.03$ & $92.14 \pm 6.51$ & $86.09 \pm 11.06$ & $86.27 \pm 7.50$ \\
\hline ANOVA & \multicolumn{4}{|c|}{$\mathrm{F}=15.755 ; \mathrm{p}<0.001$} \\
\hline Total donor exposure & 25 & 53 & 63 & 34 \\
\hline Mean donor exposure per patient & 0.6 & 0.7 & 0.6 & 0.7 \\
\hline Unused packets after issuing & 1 & 2 & 2 & 0 \\
\hline
\end{tabular}

Volume of transfusion used for neonatal transfusion was $10-20 \mathrm{ml} / \mathrm{kg}$. As the birth weight decreased, wastage of blood increased. Table 2 shows wastage of blood components. A mean wastage of around 230.80ml was present for PRBC transfusions, 308 $\mathrm{ml}$ was noted for whole blood, $171.37 \mathrm{ml}$ for FFP and $26.90 \mathrm{ml}$ for RDP transfusions. A statistically significant correlation was noted $(p<0.001)$. Maximum wastage was noted for whole blood and minimum wastage was noted for RDP transfusion

Table 2: Wastage of blood components

\begin{tabular}{|l|c|c|c|}
\hline \multicolumn{1}{|c|}{ Blood component } & $\begin{array}{c}\text { Volume of transfusion } \\
(\mathbf{m l})\end{array}$ & $\begin{array}{c}\text { Wastage } \\
(\mathbf{m l})\end{array}$ & $\begin{array}{c}\text { Wastage } \\
(\mathbf{\%})\end{array}$ \\
\hline Fresh frozen plasma - Mean \pm SD & $29.01 \pm 13.66$ & $171.37 \pm 13.98$ & $85.68 \pm 6.99$ \\
\hline Packed red blood cells - Mean \pm SD & $19.53 \pm 8.72$ & $230.80 \pm 9.01$ & $92.32 \pm 3.60$ \\
\hline Random donor platelet - Mean \pm SD & $20.60 \pm 4.33$ & $26.90 \pm 8.82$ & $54.80 \pm 14.97$ \\
\hline Whole blood - Mean \pm SD & $31.77 \pm 12.89$ & $308.23 \pm 12.89$ & $90.66 \pm 3.79$ \\
\hline ANOVA & $\mathrm{F}=17.990 ; \mathrm{p}<0.001$ & $\mathrm{~F}=1869.000 ; \mathrm{p}<0.001$ & $\mathrm{~F}=162.233 ; \mathrm{p}<0.001$ \\
\hline
\end{tabular}

Table 3 shows wastage of blood with respect to maturity. There was a statistically significant correlation between gestational age and wastage of blood ( $\mathrm{p}<0.05)$. As birth weight decreased, wastage of blood increased.

Table 3: Wastage of blood with respect to maturity

\begin{tabular}{|l|c|c|c|}
\hline \multicolumn{1}{|c|}{ Maturity } & $\begin{array}{c}\text { Volume of Transfusion } \\
(\mathbf{m l})\end{array}$ & $\begin{array}{c}\text { Wastage } \\
(\mathbf{m l})\end{array}$ & $\begin{array}{c}\text { Wastage } \\
(\mathbf{\%})\end{array}$ \\
\hline Pre-term - Mean \pm SD & $18.56 \pm 7.96$ & $216.78 \pm 46.53$ & $91.27 \pm 6.86$ \\
\hline Term - Mean \pm SD & $30.52 \pm 12.42$ & $199.86 \pm 54.37$ & $84.92 \pm 11.14$ \\
\hline Post-term - Mean \pm SD & $27.00 \pm 18.60$ & $198.00 \pm 36.69$ & $87.73 \pm 9.62$ \\
\hline ANOVA & $\mathrm{F}=45.063 ; \mathrm{P}<0.001$ & $\mathrm{~F}=3.776 ; \mathrm{P}<0.05$ & $\mathrm{~F}=16.911 ; \mathrm{P}<0.001$ \\
\hline
\end{tabular}

Maximum donor exposure was noted in those babies with birth weight 1500-2499. Maximum transfusion was noted in this group. As the requirement for transfusion increased, chance of getting exposed to multiple donors also increased. Figure 1 shows the use of blood component with respect to birth weight. Figure 2 shows the wastage of blood component 

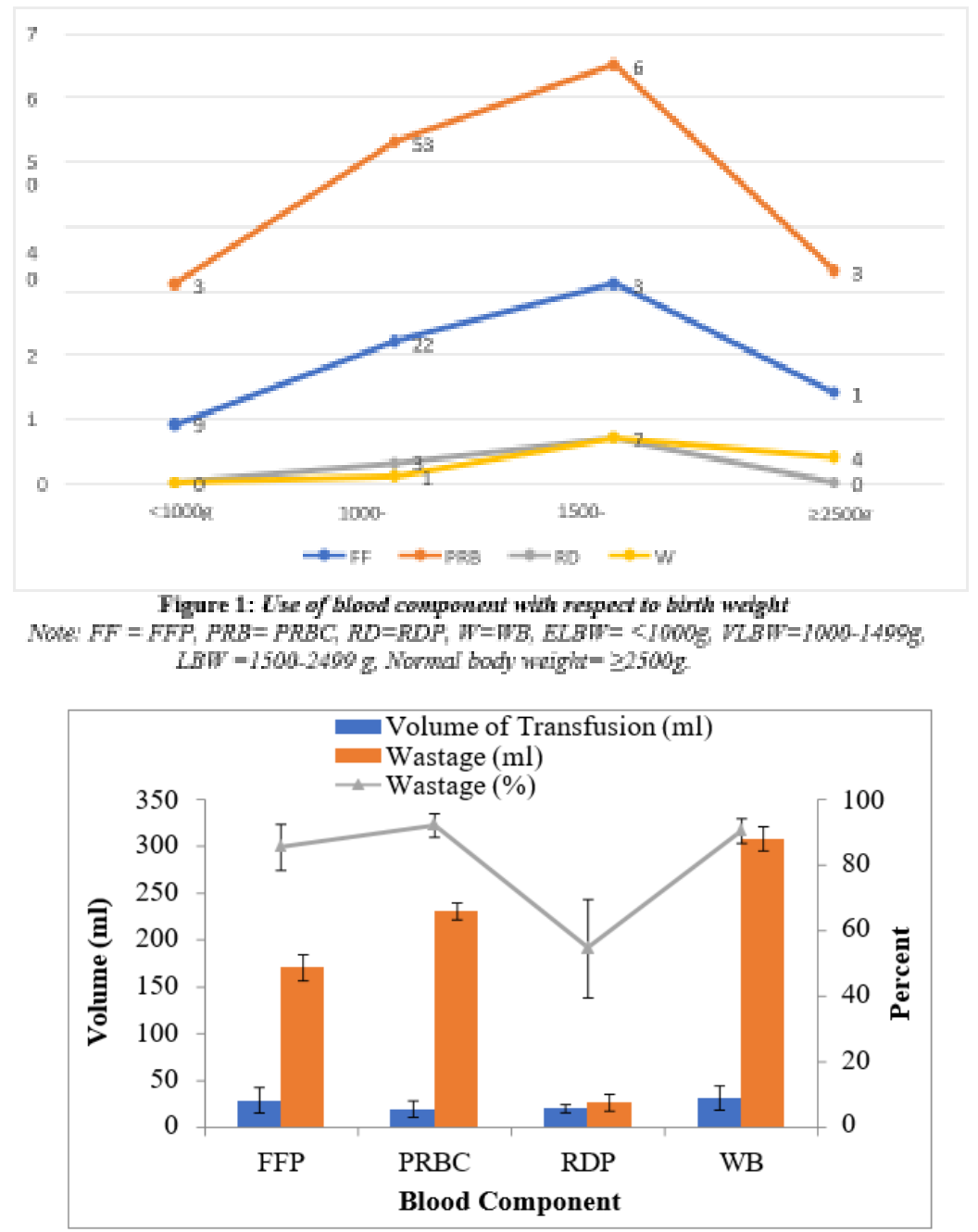

Figure 2: Wastage of blood component

Fresh Frozen Plasma (FFP), Packed RBCs (PRBC), Random Donor Platelet (RDP), Whole blood (WB)

\section{Discussion}

The need for transfusion is high among neonates, especially preterm infants. Ideally, each and every component of transfusion should be tailored to the requirement of the individual infant. From this study we have found that PRBC was the most common blood component used for transfusion in a neonatal unit, $64.8 \%$ of study subjects receiving PRBC transfusion during their period of stay in the hospital. Previous studies had similar observations ${ }^{4}$. The volume of blood packet available for transfusion was $250 \mathrm{ml}$ for PRBC, $180-220 \mathrm{ml}$ for FFP and $320-360 \mathrm{ml}$ for $\mathrm{WB}$. The mean volume of wastage was $230.80 \pm 9.01 \mathrm{ml}$ for PRBC transfusion, $171.37 \pm 13.98 \mathrm{ml}$ for FFP, $308.23 \pm$ $12.89 \mathrm{ml}$ for $\mathrm{WB}$ and $26.90 \pm 8.82 \mathrm{ml}$ for RDP. Since provision of small volume package was available for RDP compared to other blood components, the mean volume of wastage was less for RDP. In our study it was noted that the blood component was higher for preterm, ELBW babies. Transfusion requirement of these babies was significantly higher. Similar observations were noted in a study by Gupta
A, et $a l^{5}$. Gupta showed in his study the benefits of using cost-effective satellite packs in neonates. They used $30 \mathrm{ml}$ satellite packs prepared from $250 \mathrm{ml}$ packets.

$\mathrm{RBC}$ transfusion has its own risks in ELBW infants. The essential fetal factors needed for the early stage of development will get diluted by the transfusion of adult blood to an ELBW baby. Factors like fetal haemoglobin, specific for fetal development, are present in preterm infants' blood ${ }^{1}$. In our study maximum blood donor exposure was noted in babies with birth weight between 1500-2499 since frequency of transfusion was higher in this group. The mean donor exposure per patient was 0.6 . In our neonatal care centre, the ratio of donor exposure to transfusion was 1:1 (Figure 1). Cook $\mathrm{S}$, et $a l^{3}$ showed the advantages of adopting a strategy using assigned red cell units, which can minimize the donor exposure in babies who need multiple transfusions ${ }^{3}$. A fresh unit of RBCs can be reserved for a neonate at his or her first transfusion to reduce donor exposures. Aliquots of that unit can be utilized 
for further transfusions until it is depleted or expires. It is particularly useful for premature infants who require multiple transfusions.

It is always advisable to use only fresh blood for neonatal transfusions because of the risk of metabolic effects ${ }^{6}$. Stored blood has more extracellular RBC and decreased 2, 3 DPG level. Usually, for small volume transfusions, these risks would appear to be less. From our study it was noted that the mean wastage of blood loss relating to neonatal transfusion was around $90 \%$ for a period of one year (Figure 2). It is highly undesirable to have this huge amount of wastage. The huge wastage can be minimized by the proper utilization of satellite packs. Wastage can be significantly minimized and further blood can be utilized for saving the life of another sick patient. Risk of transfusion and multiple donor exposure can be minimized by strict adherence to transfusion protocol. Moreover, neonatal care is also an important factor. Delayed cord clamping at delivery is an option to reduce requirement for transfusion in the neonatal period.

\section{Conclusions}

The mean wastage of blood loss following transfusion was significantly high among newborns. As birth weight decreased wastage of blood component increased. Fresh unit of RBCs can be reserved for a neonate at his or her first transfusion to reduce donor exposures. Aliquots of that unit can be utilized for further transfusions until it is depleted or expires.

\section{Acknowledgements}

We sincerely thank Prof. Panchanan Kundu, Principal, Midnapore Medical College, Midnapore, W.B., for constant encouragement throughout the study and Sick Neonatal Care Unit, MMC, for providing data. We are also grateful to Mrs. Ancey Joseph, Statistician TDMC, and Dr. Jazeela Mohamed Siddique, PGT, Com. Medicine, TDMC, Alappuzha, Kerala, India.

\section{References}

1. Clare EC, Lisanne EH, Ratna T, Vincent B, Jap JZ, Arjan BP et al. Iatrogenic blood loss in extreme preterm infants due to frequent blood tests and procedures. Journal of Maternal-Fetal and Neonatal Medicine 2019 Oct. 6; 1-6. Online ahead of print.

https://doi.org/10.1080/14767058.2019. 1670800

PMid: 31588840

2. Roberton NR. Top up transfusion. Archives of Disease in Childhood 1987; 62: 984-6.

https://doi.org/10.1136/adc.62.10.984

PMid: 3674937 PMCid: PMC1778675

3. Cook S, Gunter J, Wissel M. Effective use of a strategy using assigned red cell units to limit donor exposure for neonatal patients. Transfusion 1993; 33-35. https://doi.org/10.1046/j.15372995.1993.3 3593255596.x

PMid: 8488540

4. Luban N. Neonatal red blood cell transfusion. Current Opinion in Hematology 2002; 9: 533- 6. https://doi.org/10.1097/000627522002110 00-00012

PMid: 12394178

5. Gupta A, Patel R, Dyke M. Cost effective use of satellite packs in neonates: importance of birth weight. Archives of Disease in Childhood Fetal Neonatal Edition 2004; 89: F182- F183. https://doi.org/10.1136/adc.2002.021147 PMid: 14977909 PMCid: PMC1756049

6. Luban NLC. Controversies in blood component use in the newborn. Immunohematology 1991; 7:1-7. 